Research Article OPEN ACCESS

\title{
Analisis Lembar Kerja Peserta Didik Sekolah Menengah Atas Pada Praktikum Uji Urin
}

\author{
(Analysis of High School Student Worksheet on Urine Test Practice)
}

Iman Ridwan*, Sri Anggraeni, Bambang Supriyatno

Universitas Pendidikan Indonesia - Bandung - Indonesia

JI. Dr. Stiabudi No. 229, Bandung, Indonesia

*Corresponding author : elrhazes@gmail.com

\begin{tabular}{|c|c|}
\hline Informasi Artikel & ABSTRACT \\
\hline $\begin{array}{l}\text { Submit: } 02-06-2020 \\
\text { Diterima: } 25-08-2020 \\
\text { Dipublikasikan: } 06-09-2020\end{array}$ & $\begin{array}{l}\text { Argumentation skills are skills that can encourage students to be involved in providing } \\
\text { facts, data and theories that are appropriate to support claims against a problem. The } \\
\text { purpose of this study is to determine the profile of written argumentation skills of } \\
\text { senior high school (SMA) students on the motion system material that has been } \\
\text { learned by students. The method in this study uses a descriptive method with a } \\
\text { qualitative approach. The research subjects were students of grade XI of Sukabumi } \\
\text { Regency State High School. Samples were taken using a purposive sampling } \\
\text { technique with a total of } 36 \text { students, who had followed the motion system material. } \\
\text { The instrument used was in the form of problem descriptions to measure students' } \\
\text { argumentation skills with a total of } 10 \text { questions that referred to the criteria level and } \\
\text { the argumentation skills of the Toulmin Argumentation Pattern (TAP). The results } \\
\text { showed that the written argumentation skills of Grade XI students of the State Senior } \\
\text { High School in Sukabumi Regency in the academic year } 2019 / 2020 \text { were still in the } \\
\text { low category, this was indicated by the highest percentage results at level } 1 \text { namely } \\
38 \% \text { and level } 2 \text { at } 36 \% \text {. While the highest percentage based on indicator criteria is } \\
83 \% \text { on the claim indicator. Therefore the students 'written argumentation skills must } \\
\text { be improved by using methods, models and learning approaches that are able to } \\
\text { practice students' written argumentation skills. } \\
\text { Keywords: Student's worksheet, The Excretion System, Urine Test }\end{array}$ \\
\hline Penerbit & ABSTRAK \\
\hline $\begin{array}{l}\text { Program Studi Pendidikan } \\
\text { Biologi, Fakultas Keguruan dan } \\
\text { IImu Pendidikan, Universitas } \\
\text { Jambi }\end{array}$ & $\begin{array}{l}\text { Lembar Kerja Peserta Didik (LKPD) sangat bermanfaat bagi siswa dalam kegiatan } \\
\text { praktikum untuk menstimulasi pembentukan konsep secara utuh yang sebelumnya } \\
\text { sudah didapatkan baik dari studi literatur atau penyampaian dari guru di dalam kelas. } \\
\text { Penelitian ini bertujuan untuk menjelaskan analisis serta uji coba dari beberapa } \\
\text { LKPD praktikum yang mengacu pada kurikulum KTSP dan kurikulum } 2013 \text {. Metode } \\
\text { penelitian yang digunakan adalah deskriptif kuantitatif. Metode penelitian yang } \\
\text { digunakan dalam penelitian ini adalah metode deskriptif kuantitatif. Sampel dalam } \\
\text { penelitian ini berjumlah } 5 \text { LKPD Uji Urin yang dipilih dengan menggunakan teknik } \\
\text { purposive sampling. Instrumen penelitian yang digunakan dalam penelitian ini adalah } \\
\text { rubrik analisis konseptual, prosedural, dan konstruksi pengetahuan, rubrik } \\
\text { kelengkapan komponen LKPD, dan rubrik penskoran komponen LKPD berdasarkan } \\
\text { Diagram Vee yang diadaptasi dari Novak dan Gowin (1984). Hasil penelitian } \\
\text { menunjukkan bahwa secara konseptual LKPD Uji Urin yang dianalisis belum memuat } \\
\text { konten dan melatih kompetensi (pengetahuan dan keterampilan) yang sesuai dengan } \\
\text { tuntutan Kurikulum } 2013 \text {. Secara prosedural, LKPD Uji Urin yang dianalisis dapat } \\
\text { dilaksanakan dengan baik, tetapi sebagian besar belum relevan dengan tujuan } \\
\text { praktikum dan tuntutan kompetensi dasar di kurikulum. Dari segi konstruksi } \\
\text { pengetahuan, LKPD Uji Urin yang dianalisis belum membantu peserta didik untuk } \\
\text { mengonstruksi pengetahuannya secara utuh yang terdiri dari konsep, prinsip, dan } \\
\text { teori melalui berbagai fakta yang dihasilkan. Ditinjau dari strukturnya, hampir seluruh }\end{array}$ \\
\hline
\end{tabular}


LKPD Uji Urin yang dianalisis memiliki komponen Diagram Vee lengkap, meskipun dengan perbedaan kualitas yang ditunjukkan oleh capaian skor dari masing-masing komponen Diagram Vee. Berdasarkan permasalahan-permasalahan yang ditemukan, LKPD Uji Urin memerlukan rekonstruksi dari sisi konseptual, prosedural, konstruksi pengetahuan, maupun strukturnya.

Katakunci: : Lembar Kerja Peserta Didik, Sistem Ekskresi, Uji Urin

This BIODIK : Jurnal IImiah Pendidikan Biologi is licensed under a CC BY-NC-SA (Creative Commons Attribution-ShareAlike 4.0 International License)

\section{PENDAHULUAN}

Praktikum adalah pembelajaran yang dilakukan pada suatu tempat tertentu dimana siswa berperan secara aktif dalam menyelesaikan rubrik/ problem yang diberikan melalui penggunaan alat, bahan, metode tertentu (Syam, 2003). Praktikum merupakan bagian yang tidak terpisahkan dari pembelajaran sains yang bertujuan untuk memberi kesempatan kepada siswa untuk melakukan pengujian hipotesis atau observasi objek nyata berkaitan dengan konsep atau teori. Praktikum juga diartikan sebagai kerja laboratorium atau kerja praktik yang dilakukan di laboratorium berkaitan dengan bidang ilmu. Adapun praktik dapat didefinisikan sebagai cara melakukan sesuatu atau cara melakukan apa yang tersebut dalam teori (Rustaman, dkk, 2006). Bentuk praktikum menurut Woolnough (2003) terdiri atas praktikum yang bersifat latihan, praktikum yang bersifat memberi pengalaman, dan praktikum yang bersifat investigasi atau penyelidikan. Ketiga bentuk praktikum tersebut penting dibekalkan kepada calon guru. Praktikum bentuk latihan bertujuan untuk mengembangkan keterampilan dasar, seperti menggunakan alat, mengukur, dan mengamati. Contoh praktikum bersifat latihan adalah berlatih menggunakan mikroskop. Praktikum bentuk pengalaman bertujuan untuk meningkatkan pemahaman materi pelajaran. Contoh praktikum bentuk pengalaman adalah eksplorasi respons fisiologis sejenis tumbuhan. Sedangkan praktikum bentuk investigasi bertujuan untuk mengembangkan kemampuan memecahkan masalah. Pada praktikum ini siswa dituntut dapat bertindak sebagai seorang scientist (Rustaman, dkk, 2006).

Begitu banyak buku-buku panduan praktikum yang sudah tersedia dan dipakai oleh Instansi Pendidikan khususnya Sekolah. Buku tersebut adalah pengayaan tambahan selain buku paket untuk dijadikan pegangan dalam melaksanakan kegiatan praktikum ini. Namun banyak sekali buku-buku panduan tersebut yang isinya keliru bahkan melenceng jauh dari ketetapan kurikulum yang harus dicapai guna menghasilkan pembelajaran yang efektif dan tepat sasaran. Pengarang dari buku-buku keliru tersebut ternyata bukan dari praktisi pendidikan melainkan dari praktisi bidang murni non-pendidikan, sehingga tak ayal isi dari buku-buku panduan tersebut sangat jauh dari karakteistik pendidikan (Supriatno, 2013).

Pengadaan sebuah penuntun praktikum yang dipakai untuk kalangan akademis mulai dari tingkat dasar hinigga tingkat atas haruslah sesuai dengan aturan prinsipprinsip yang ideal sebuah instrumen praktikum. Prinsip-prinsip pembelajaran 
praktikum yang harus diperhatikan yaitu: prinsip demonstrasi, aplikasi pengetahuan, berpusat pada tugas, aktifasi pengetahuan dan pengalaman, integrasi pengetahuan dalam kehidupan sehari-hari (Sofyan, 2016), bersifat student centre learning, learning by doing, mengembangkan kemampuan sosial, keingintahuan, problem solving skill, kreativitas dan berprinsip pada konsep belajar sepanjang hayat (Sofyan, 2016). Pendidik perlu memfasilitasi peserta didik dalam melakukan kegiatan praktikum yang dapat menerapkan prinsip-prinsip pembelajaran praktikum tersebut untuk mencapai tujuan pembelajaran praktikum tercapai.

Dalam pembelajaran dengan praktikum ini, peserta didik diberi kesempatan untuk mengalami sendiri atau melakukan sendiri, mengikuti suatu proses, mengamati suatu objek, menganalisis, membuktikan, dan menarik kesimpulan sendiri mengenai suatu objek, keadaan, atau proses sesuatu. Kegiatan-kegiatan tersebut merupakan inti dalam sebuah kegiatan praktikum. Sehingga dapat dikatakan bahwa baiknya suatu proses pembelajaran harus ada konsep aplikatif dari peserta didik. Dengan begitu, mereka akan memperoleh gambaran nyata terhadap teori-teori yang telah didapat dari pembelajaran di kelas. Akan tetapi dalam praktiknya di lapangan, banyak sekali permasalahan yang sering dialami peserta didik dalam kegiatan praktikumnya. Kesulitan tersebut dapat terjadi pada tahap perencanaan, pelaksanaan maupun dalam pengkomunikasian data hasil praktikum. Sehingga permasalahan yang mungkin terjadi adalah karena belum dikuasainya materi yang telah diajarkan guru dalam pembelajaran di kelas, sehingga peserta didik belum mempunyai cukup bekal dalam memahami kegiatan berikutnya yaitu dalam melakukan praktikum. Dengan belum dikuasainya materi, maka akan memberi dampak kesulitan pada peserta didik dalam melakukan praktikum (Sofyan, 2016).

Selain itu, permasalahan yang sering dihadapi peserta didik yang menyebabkan kesulitan dalam belajar praktikum adalah dalam memahami petunjuk praktikum, mungkin dari desain, tidak jelasanya materi dalam petunjuk praktikum, kata-kata asing yang baru dikenal oleh peserta didik atau dari segi bahasanya sendiri yang sulit memang dimengerti oleh peserta didik.

Selain petunjuk praktikum, permasalahan yang menyebabkan peseta didik kesulitan belajar praktikum adalah dapat terjadi karena masih kurangnya pemahaman peserta didik dalam mengetahui alat dan bahan dalam praktikum serta cara menggunaan alat dan bahan tersebut. Selain itu, permasalahan yang menyebabkan kesulitan peserta didik dalam praktikum adalah masalah dalam pembuatan laporan hasil praktikum yaitu dalam membuat pembahasan, menjawab pertanyaan, dan membuat kesimpulan (Sofyan, 2016). Permasalahan-permasalahan tersebut dapat terjadi di sekolah-sekolah yang menyelenggarakan kegiatan praktikum. Untuk menunjang kegiatan praktikum, dibutuhkan sebuah pedoman yang dapat mengarahkan siswa yang mana berperan dalam mengkonstruksi pengetahuannya berdasarkan fenomena yang muncul. Namun kenyataannya, LKPD yang digunakan di sekolah masih memiliki permasalahan.

Kemudian menurut Supriatno (2013) menemukan bahwa DKL yang beredar di lapangan memiliki permasalahan yaitu: (1) tujuan praktikum lebih banyak 
menekankan aspek kognitif daripada aspek psikomotor; (2) sebagian besar menggunakan pendekatan deduktif dengan model ekspositori; (3) prosedur praktikum meskipun rinci, beberapa di antaranya tidak terstruktur dan perintahnya membingungkan sehingga menimbulkan penafsiran ganda; serta (4) pemilihan materi tidak mempertimbangkan esensi, kesesuaian, kedalaman dan kompleksitasnya. Pada kurikulum yang berlaku di tingkat SMA, materi sistem ekskresi dituntut juga untuk diajarkan dengan cara melakukan praktikum. Biasanya pada materi sistem ekskresi ini dilakukan praktikum uji urin. Sistem ekskresi ini adalah materi yang sifatnya abstrak sehingga perlu diakukan praktikum uji urin agar pemahaman siswa lebih baik. Namun pada praktiknya, penulis telah menganalisis bahwa masih ada beberapa hal yang tidak relevan pada praktikum ini dengan konsep yang diajarkan tentang materi sistem ekskresi.

\section{METODE PENELITIAN}

Metode penelitian yang digunakan dalam penelitian ini adalah metode deskriptif kuantitatif, bertujuan untuk memaparkan keadaan objek dan/atau fenomena yang ditemukan. Penelitian ini berusaha untuk menjelaskan tentang keadaan Lembar Kerja Peserta Didik (LKPD) praktikum uji urin yang terdapat di buku paket biologi SMA kelas XI Kurikulum Tingkat Satuan Pendidikan (KTSP) 2006 dan Kurikulum 2013. Sampel dalam penelitian ini dipilih dengan menggunakan teknik purposive sampling dan berjumlah 5 LKPD, dan dari 5 LKPD tersebut, 3 LKPD disusun untuk memenuhi tuntutan kompetensi dasar di kurikulum 2013 sedangkan 2 LKPD lainnya disusun untuk memenuhi kurikulum KTSP.

Dalam penelitian ini, adapun rubrik instrumen yang digunakan adalah rubrik analisis konseptual, prosedural, konstruksi pengetahuan, rubrik kelengkapan komponen LKPD, dan rubrik penskoran komponen LKPD berdasarkan Diagram Vee yang diadaptasi dari Novak dan Gowin (1984). Data yang diperoleh dari rubrik kelengkapan komponen LKPD dan rubrik penskoran komponen LKPD berdasarkan Diagram Vee kemudian diolah ke dalam bentuk persentase (\%). Kegiatan analisis dan pengujian langkah kerja pada LKPD uji urin yang dicuplik dilakukan tanpa melakukan perubahan apapun terhadap alat dan bahan, serta langkah kerja praktikum.

\section{HASIL DAN PEMBAHASAN}

\section{Analisis Konseptual Lembar Kerja Peserta Didik (LKPD) Uji Urin}

Mengacu pada kesesuaian konten dengan kompetensi dasar, seluruh praktikum uji urin baik yang terdapat pada LKPD KTSP maupun LKPD kurikulum 2013 sama-sama mengacu pada kompetensi dasar 3.9 yang berbunyi "Menganalisis hubungan antara struktur jaringan penyusun organ pada sistem ekskresi dan mengaitkannya dengan proses ekskresi sehingga dapat menjelaskan mekanisme serta gangguan fungsi yang mungkin terjadi pada sistem ekskresi manusia melalui studi literatur, pengamatan, percobaan, dan simulasi". Dari ke 5 LKPD yang dianalisis, untuk tujuan dari pelaksanaan praktikumnya sudah sesuai dengan 
kompetensi dasar yaitu bertujuan untuk menganalisis gangguan pada sistem ekskresi melalui uji urin. Namun, uji urin tidak bisa dijadikan acuan mengenai gangguan sistem ekskresi secara keseluruhan. Kemudian dalam membangun pengetahuan siswa, praktikum ini belum bisa memenuhi harapan yang tertuang dalam KD 3.9, karena praktikum uji urin ini umumnya hanya sekedar menganalisis kandungan yang terdapat dalam urin orang yang sehat dan urin orang yang dicurigai mengidap penyakit tertentu. Lalu kemudian setelah dianalisis, ada 1 LKPD kurikulum 2013 yang tidak menyertakan tujuan praktikum sehingga menimbulkan bias dalam pengintegrasiannya dengan kompetensi dasar yang telah ditentukan, sedangkan 4 LKPD sisanya menuliskan tujuan pelaksanaan praktikum.

\section{Analisis Prosedural Lembar Kerja Peserta Didik (LKPD) Uji Urin}

Peralatan dan bahan-bahan yang dicantumkan pada LKPD semuanya sudah sesuai dengan alat dan bahan yang memang dibutuhkan. Namun 4 LKPD hanya mencamtumkan sebatas alat dan bahan tanpa takaran sehingga memungkinkan para siswa yang melaksanakan praktikum tersebut akan kebingungan, walaupun hal tersebut dapat diatasi dengan cara siswa bertanya pada guru secara langsung namun dilihat dari keefektifan dan efisiensi waktu hal tersebut bisa menjadi hambatan pelaksanaan praktikum dan hanya 1 LKPD yang mencantumkan alat dan bahan beserta jumlah serta takaran yang memang dibutuhkan. Kemudian langkahlangkah praktikum yang tercatat dalam LKPD semuanya terstruktur serta dapat diikuti/dilakukan oleh siswa, namun 1 dari 4 LKPD yang benar-benar menuliskan langkah-langkah praktikum dengan dilengkapi alokasi waktu pada beberapa langkahnya, misalkan dalam memanaskan urin yang sudah dicampur dengan reagen biuret perhatikan perubahan yang terjadi selama 5 menit pembakaran, sedangkan 4 LKPD lainnya tidak menyertakan alokasi waktu pada beberapa langkah pelaksanaan. Kemudian objek/fenomena yang diperintahkan dalam langkah praktikum seluruhnya muncul berupa perubahan zat dan warna pada urin yang dicampur dengan berbagai reagen, ini menandakan langkah-langkah praktikum yang disusun dalam LKPD seluruhnya bisa memunculkan objek/fenomena. Kemudian perekaman data berupa tabel atau bentuk interpretasi lainnya hanya tersedia pada 3 LKPD saja dan perekaman data tersebut berbentuk tabel, sedangkan 2 LKPD sisanya tidak memuat perekaman data baik berupa tabel ataupun berupa bentuk lainnya. Kemudian relevansi objek/fenomena yang muncul dengan tujuan praktikum sudah sesuai, karena 4 LKPD yang memuat tujuan praktikum bunyinya hampir sama yaitu seputar "menganalisis perubahan kandungan dan warna pada urin" dan ketika dilakukan pengujian, objek/fenomena yang muncul menggambarkan tujuan praktikum itu sendiri dan hanya 1 LKPD yang tidak memuat tujuan praktikum sehingga bisa dikatakan tidak ada kaitan dan relevansi antara objek/fenomena dengan tujuan praktikum itu sendiri. Kemudian terkait alokasi waktu pelaksanaan praktikum hanya 2 LKPD dari 5 LKPD yang memuat alokasi waktu praktikum serta LKPD yang memuat petunjuk safety lab hanyalah 2 LKPD selebihnya tidak ada sama sekali himbauan atau petunjuk safety lab. 


\section{Analisis Rekonstruksi Pengetahuan Lembar Kerja Peserta Didik (LKPD) Uji Urin}

Rekonstruksi pengetahuan pada LKPD berupa butir-butir pertanyaan yang sifatnya mengkonstruk pemahaman konsep. Semua LKPD yang dianalisis memiliki butir pertanyaan yang beragam jumlahnya, namun esensi pertanyaan-pertanyaan tersebut berbeda-beda ada yang mengkonstruk pemahaman konsep dan adapula yang tidak. Kemudian beberapa pertanyaan pada LKPD ada yang bisa dijawab dengan praktikum itu sendiri dan adapula yang tidak. Dari 5 LKPD yang dianalisis, ternyata semuanya terdapat butir pertanyaan yang bisa dijawab dengan praktikum, dan pertanyaan yang bisa dijawab dengan melalui pencarian literatur. Kemudian semua pertanyaan dari kelima LKPD tersebut didominasi oleh pertanyaan yang mana jawabannya hanya seputar fenomena yang ditemukan didalam praktikum contohnya "apakah yang terjadi setelah penambahan $\mathrm{AgNO}^{3}$ pada urin?", sedangkan pertanyaan yang mengarah pada konstruksi pemahaman konsep hanya 1 LKPD saja dari 5 LKPD yang dianalisis, itupun hanya 1 butir pertanyaan yang berbunyi "jenis penyakit apakah yang menyebabkan urin mengandung kadar protein dengan jumlah melebihi batas normal?". Pertanyaan tersebut mengacu pada kompetensi dasar 3.9 di awal dan mengacu pada sub-materi mengenai gangguan pada sistem ekskresi. Kemudian tidak adanya pertanyaan fakta yang mengarah pada konstruksi konsep, sebaliknya fakta yang ditanyakan hanya memperkuat hasil percobaan pada praktikum. Lalu pertanyaan yang mengarah pada kemunculan suatu prinsip hanya ada 1 butir dalam 1 LKPD yaitu seperti ini "jelaskan hubungan kadar protein dalam urin dan kesehatan!". Kemudian penarikan kesimpulan terdapat pada semua LKPD yang dianalisis dan 3 diantaranya meminta uraian kesimpulan berdasarkan data dan menggambarkan judul serta tujuan praktikum, sedangkan 2 LKPD sisanya mengemukakan kesimpulan yang kurang begitu jelas dan terkesan langsung memerintahkan untuk siswa menyimpulkan begitu saja.

\section{Analisis Kelengkapan dan Skor Komponen Lembar Kerja Peserta Didik (LKPD) Berdasarkan Diagram Vee}

Berdasarkan tabel diagram vee dibawah, menunjukan bahwa LKPD yang dianalisis seimbang dilihat dari kelengkapan komponen diagram vee namun masih didominasi oleh LKPD yang memiliki komponen lengkap diagram vee, namun tetap komponen-komponen tersebut memiliki skor dan pencapaian kualitas yang berbedabeda.

Tabel 1. Hasil Analis Diagram Vee

\begin{tabular}{llll}
\hline \multirow{2}{*}{ No } & \multirow{2}{*}{ Komponen Diagram Vee } & \multicolumn{2}{l}{ Keberadaan } \\
\cline { 3 - 4 } & & Ya & Tidak \\
\hline 1. & Pertanyaan fokus & 4 LKPD & 1 LKPD \\
\hline 2. & Objek/ peristiwa & 5 LKPD & - \\
\hline 3. & Konsep/ prinsip/ teori & 2 LKPD & 3 LKPD \\
\hline 4. & Catatan/ transformasi & 3 LKPD & 2 LKPD \\
\hline 5. & Klaim pengetahuan & 5 LKPD & - \\
\hline
\end{tabular}


Komponen pertanyaan fokus dan objek/ peristiwa memiliki skor maksimum 3, sementara komponen konsep/ prinsip/ teori, catatan/ transformasi dan klaim pengetahuan memiliki skor maksimum 4. Sebanyak 2 LKPD Uji Urin memperoleh skor 3 dan 2 LKPD uji urin mendapat skor 1 serta 1 sisanya mendapatkan skor 0 untuk komponen pertanyaan fokus yang menunjukkan bahwa 2 LKPD yang mendapatkan skor 3 tersebut memiliki pertanyaan fokus yang dapat diidentifikasi dengan jelas dan mendukung kemunculan objek/ peristiwa. LKPD yang memiliki pertanyaan fokus menandakan bahwa LKPD tersebut mampu mengarahkan peserta didik untuk memperoleh apa yang seharusnya mereka temukan dalam kegiatan laboratorium (Millar \&Abraham, 2009), meskipun pertanyaan fokus pada 2 LKPD Uji Urin lainnya belum memperoleh skor maksimum. Adapun pertanyaan-pertanyaan fokus di LKPD tersebut dapat ditemukan secara jelas di tujuan praktikum ataupun secara tersirat di judul praktikum.

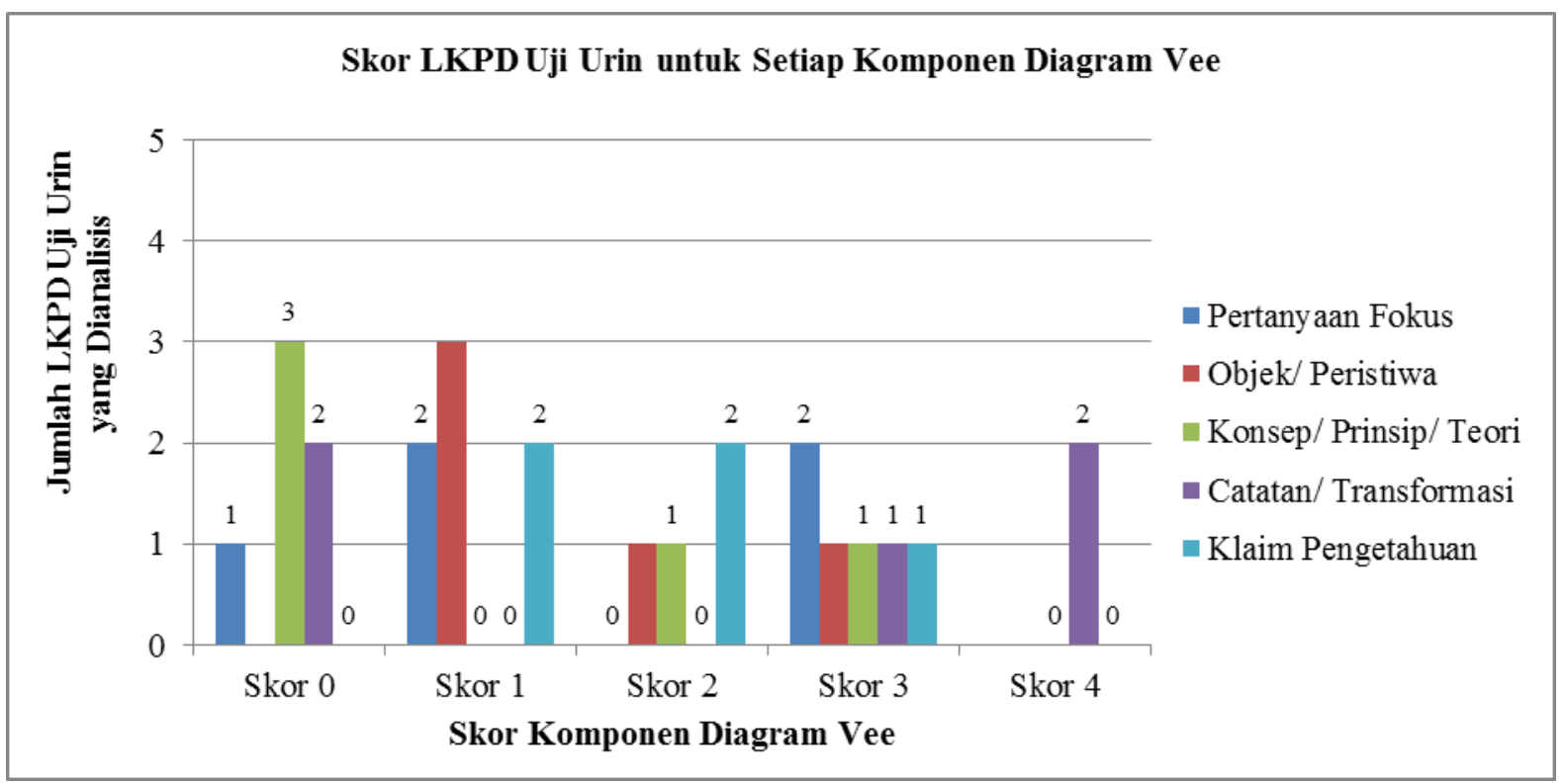

Gambar 1: Diagram Skor LKPD

Sebanyak 3 LKPD Uji Urin memperoleh skor 1 untuk komponen objek/ peristiwa kemudian yang mendapatkan skor 2 ada 1 LKPD dan yang mendapatkan skor 3 ada 1 LKPD hal tersebut menunjukkan bahwa LKPD yang dianalisis kebanyakan objek dan/atau peristiwa yang diidentifikasi tidak konsisten dengan pertanyaan fokus yang terdapat di judul atau tujuan praktikum. Temuan ini sejalan dengan penelitian sebelumnya yang dilakukan oleh Supriatno (2013) yang menyatakan bahwa salah satu penyebab ketidakkonsistenan objek/ peristiwa yang ditemukan dengan pertanyaan fokus adalah karena adanya kesalahan pada prosedur kerja atau prosedur kerja yang tidak lengkap. Sebanyak 3 LKPD Uji Urin memperoleh skor 0 untuk komponen konsep/ prinsip/ teori, 1 LKPD mendapatkan skor 2 dan 1 LKPD sisanya mendapatkan skor 3 hal tersebut menunjukkan bahwa hanya sedikit konsep yang dapat dibangun dari kegiatan praktikum, tanpa disertai dengan pembentukan prinsip dan teori. Sebanyak 2 LKPD Uji Urin memperoleh skor 4 untuk komponen catatan/ transformasi, 1 LKPD mendapatkan skor 3 dan 2 LKPD 
sisanya mendapatkan skor 0 hal tersebut menunjukkan bahwa kegiatan pencatatan dapat diidentifikasi di LKPD dan sesuai dengan peristiwa utama. Kemudian hanya 1 LKPD Uji Urin memperoleh skor 3 untuk komponen klaim pengetahuan, 2 LKPD mendapatkan skor 2 dan 2 LKPD sisanya mendapatkan skor 1 hal tersebut menunjukkan bahwa klaim pengetahuan yang dibentuk mengandung konsep-konsep yang sesuai dengan pertanyaan fokus dan hasil pencatatan dan transformasi, tetapi belum mengarah kepada pembentukan pertanyaan fokus baru.

Seharusnya pelaksanaan praktikum bisa membantu mengkonstruk pengetahuan siswa terhadap suatu materi. Sebagaimana yang dikatakan Millar (2004) bahwasanya kegiatan praktikum berperan untuk membantu siswa menghubungkan antara dua ranah pengetahuan, yaitu objek atau fenomena yang teramati dan ranah gagasan atau ide. Seharusnya praktkum bisa dijadikan moment untuk menambah wawasan keilmuan siswa dan seharusnya melalui kegiatan praktikum, siswa dilatih untuk mengembangkan kemampuan kognitif, afektif dan psikomotorik dalam memahami suatu fenomena biologi (Suparnno, 2000). Kegiatan praktikum juga sangat diperlukan untuk menunjang materi ajar karena menurut Purwanto (2009) kegiatan praktikum dapat membantu siswa dalam memahami konsep-konsep yang sulit dan abstrak. Dalam pelaksanaan praktikum selain menguasai pengetahuan prosedural, siswa dapat menguasai pengetahuan faktual dan konseptual karena seringkali pengetahuan prosedural merupakan langkahlangkah untuk mendapatkan pengetahuan faktual dan pengetahuan konseptual (Anderson dan Krathwohl, 2010).

\section{KESIMPULAN}

LKPD Uji Urin yang dianalisis belum memuat konten dan melatih kompetensi (pengetahuan dan keterampilan) yang sesuai dengan tuntutan Kurikulum 2013. LKPD Uji Urin yang dianalisis dapat dilaksanakan dengan baik, tetapi sebagian besar belum relevan dengan tujuan praktikum dan tuntutan kompetensi dasar di kurikulum. LKPD Uji Urin yang dianalisis belum membantu peserta didik untuk mengonstruksi pengetahuannya secara utuh yang terdiri dari konsep, prinsip, dan teori melalui berbagai fakta yang dihasilkan. Fakta yang tersaji dalam bentuk data pengamatan juga belum digali secara optimal melalui proses interpretasi data. Dari segi kelengkapan dan skor komponen LKPD berdasarkan Diagram Vee, hanya sebagian kecil LKPD Uji Urin yang tidak memiliki komponen Diagram Vee lengkap. Meskipun demikian, komponen-komponen tersebut memiliki perbedaan kualitas yang ditunjukkan oleh capaian skor dari masing-masing komponen Diagram Vee.

\section{DAFTAR PUSTAKA}

Anderson \& Krathwohl. (2010). Kerangka Landasan Untuk Pembelajaran, Pengajaran dan Asesmen. Yogyakarta: Pustaka Pelajar. 
Hewson, M. G. \& Hewson, P. W. (2003). Effect of instruction using students prior knowledge and conceptual change strategies on science learning. Nation of Research in Science Teaching. Vol. 40. Supplement. 586-598.

Millar, R. (2004). The Role of Practical Work in The Teaching and Learning of Science. Washington DC. National Academy of Sciences.

Purwanto. (2009). Evaluasi Hasil Belajar, Yogyakarta: Pustaka Pelajar.

Rahman, T., Rustaman, N., Sukmadinata, N.S., dan Poedjaji, A. (2006). "Profil kemampuan generic perencanaan percobaan calon guru hasil pembelajaran berbasis kemampuan generic pada praktikum fisiologi tumbuhan". Jurnal Pendidikan dan Budaya Educare. 4 (1), $72-87$.

Rustaman, A. \& Wulan, A. R. (2007). Strategi Pembelajaran Biologi. Bandung: Universitas Terbuka.

Sofyan, Herminarto. (2016). Penyusunan Panduan Praktikum. Applied Approach Buku 2. UNY Press: Yogyakarta

Suparno, P. (2000). Teori Perkembangan Kognitif Jean Piaget. Yogyakarta: Kanisius.

Supriatno, B. (2007). Profil Lembar Kegiatan Biologi Siswa Sekolah Menengah. Proceding Seminar Nasional Jurusan Pendidikan Biologi

Supriatno, B. (2013). Pengembangan Program Perkuliahan Pengembangan Praktikum Biologi Sekolah Berbasis ANCORB untuk Mengembangkan Kemampuan Merancang dan Mengembangkan Desain Kegiatan Laboratorium. Disertasi Jurusan Pendidikan Biologi FPMIPA UPI: Tidak diterbitkan.

Sudijono, Anas. (2006). Pengantar Evaluasi Pendidikan, Jakarta : Grafindo Persada.

Syam, Machmud. (2003). Praktikum. Materi presentasi pada pelatihan program

Wahidah N.S, Supriyatno B, Kusumastuti M.N, (2018). Analisis Struktur dan Kemunculan Tingkat Kognitif pada Desain Kegiatan Laboratorium Materi Fotosintesis. Indonesian Journal of Biology Education, ISSN 2621-7260 (Online). 